\title{
Distribution characteristics of combat-related shrapnel and relationship to weapon type and conflict location: Experience of an operational field hospital
}

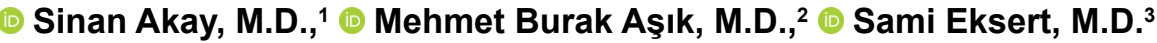 \\ ${ }^{1}$ Department of Radiology, Dr. Aşkım Tüfekçi State Hospital, Adana-Turkey \\ 2Department of Ear-Nose-Throat Diseases, Gülhane Training and Research Hospital, Ankara-Turkey \\ ${ }^{3}$ Department of Anesthesia and Reanimation, Gülhane Training and Research Hospital, Ankara-Turkey
}

\begin{abstract}
BACKGROUND: The aim of this study was to investigate the characteristics of shrapnel distribution in the body and a possible relationship to the type of weapon and type of location of the conflict.

METHODS: The records of 246 patients admitted to a level-III trauma center with any kind of firearm injury were examined retrospectively. Ninety patients who had at least I radiologically-proven piece of shrapnel in their body were included in the study. For the purposes of the study, the body was divided into 5 regions (head/neck, thorax/back, abdomen/pelvis/waist, upper extremities, and lower extremities) and shrapnel distribution was noted according to these divisions. Medical data and detailed information regarding the weapon type (long-barreled weapon, rocket-propelled grenade [RPG], or improvised explosive device [IED]), conflict location (residential or rural area), and all radiological examinations (radiography and/or computed tomography) were carefully reviewed. The relationship between these variables and the shrapnel distribution in the body was investigated.
\end{abstract}

RESULTS: No statistically significant differences were seen between weapon type and shrapnel distribution ( $p>0.05)$, except a significantly higher percentage of head/neck region shrapnel injuries as a result of RPG and IED injuries $(p=0.002)$. There was no statistically significant relationship between the shrapnel distribution characteristics and conflict location, classified as either residential or rural $(p>0.05)$.

CONCLUSION: Secondary blast injuries induced by penetrating shrapnel are the most common type of explosion- and combatrelated injuries. In the current study, a significantly higher rate of head/neck region shrapnel injuries was observed in RPG and IED injuries compared with long-barreled weapon-induced injuries. The primary reason is likely the more unexpected nature of those 2 types of attacks, which allow no time to shield that part of the body.

Keywords: Blast injury; combat-related injury; computed tomography; radiography; shrapnel.

\section{INTRODUCTION}

Blast injuries are commonly classified as primary, secondary, tertiary, or quaternary. Primary blast injuries are overpressure injuries due to explosion effects. Secondary injuries are caused by traveling shrapnel fragments secondary to the explosion, while tertiary injuries are due to falling or being thrown due to the power of the blast. Quaternary blast in- juries are caused by fire, radioactive and biological agents, and chemicals related to the explosion. ${ }^{[1,2]}$

In recent years, global terrorism has become a larger concern all over the world, and armed terrorist groups perform many sensational acts targeting both city centers and rural areas. They often use tactics and weapons such as ambush trap-bombs, improvised explosive devices (IEDs), and rock-

Cite this article as: Akay S, Aşık MB, Eksert S. Distribution characteristics of combat-related shrapnel and relationship to weapon type and conflict location: Experience of an operational field hospital. Ulus Travma Acil Cerrahi Derg 2018;24:587-593.

Address for correspondence: Sinan Akay, M.D.

Eski Adana Asker Hastanesi, Radyoloji Bölümü, 01010 Adana, Turkey

Tel: +90 322 - 2399339 E-mail: akaysinan04@yahoo.com

Ulus Travma Acil Cerrahi Derg 2018;24(6):587-593 DOI: 10.5505/tjtes.2018.13402 Submitted: 22.06.2017 Accepted: 16.04.2018 Online: 09.1I.2018

Copyright 2018 Turkish Association of Trauma and Emergency Surgery 
et-propelled grenades (RPGs) as part of their attacks. As a result, various blast and weapon injuries have become a more common reason for hospital admissions. Among those admissions, secondary blast injuries induced by penetrating shrapnel are the most common source of explosion- and combatrelated injuries. ${ }^{[2,3]}$

Shrapnel damage is an important subset of blast injury. Depending on the shape, weight, and size of the fragment, as well as the distance from the explosion, shrapnel may cause both low- and high-energy injuries. ${ }^{[4,5]}$ Shrapnel distribution in the body depends primarily on tissue resistance. ${ }^{[6]}$

The objective of this research was to investigate the distribution characteristics of shrapnel caused by firearm injuries, and the possible relationship between distribution and weapon type (long-barreled weapon, RPG, or IED). The relationship between weapon type, conflict location (residential versus rural), and shrapnel distribution was also examined.

\section{MATERIALS AND METHODS}

Review board approval was obtained from Kecioren Training and Research Hospital for this retrospective study. The medical data and radiological examinations of 246 cases of a firearm injury of any type who presented at this level-III trauma center between June 2015 and January 2016 were reviewed. The data were gathered during military operations in the southeastern part of Turkey, and all of the patients were either soldiers or police officers. Radiological examinations, including plain radiography and computed tomography (CT), were carefully examined for shrapnel. Excluded were patients with no shrapnel evidenced in their body, including those who did not undergo any radiological investigation because of immediate transfer to the operating room and those with only entire bullets in their body without shrapnel fragments. Ninety patients with at least I shrapnel fragment, confirmed by either visual examination, radiography, and/or CT were included in the study.

The localization of the shrapnel was classified as in the region of the head/neck, thorax/back, abdomen/pelvis/waist, upper extremity (arm/forearm/hand), or lower extremity (thigh/leg/ foot).

The injuries were also divided into 3 groups according to weapon type. The first group consisted of shrapnel injuries exclusively from long-barreled weapons. Those injuries were mainly bullet fragments that entered the body just after being shot into a nearby object, such as a wall, glass, or metal. Injuries caused by RPGs comprised the second group. Patients in the third group had IED injuries.

The type of location of the conflict was also noted. In the analyzed time interval, there were conflicts in both city centers and rural areas. For this reason, we wanted to investigate a possible difference in shrapnel distribution characteristics between injuries that occurred in city centers and those that occurred in rural areas. The conflicts that occurred in areas outside a city center were classified as rural, and those that occurred in city centers were classified as residential.

In some of the patients, the injuries were heterogeneous. In addition to shrapnel injuries, bullet wounds, injuries associated with the blast effects of IEDs and RPGs, injuries caused by a fall during the conflict, and combinations of these injuries were noted. Additionally, most of the patients had shrapnel in more than I body region, and this significantly complicated the picture. As a result of this heterogeneity of injuries, identifying an exact injury pattern specific to shrapnel was very difficult in some cases. Due to this complicated situation, the distribution characteristics of the shrapnel, which was the only common point in the study group, and the relationship to the variables of conflict location and weapon type, rather than the injury pattern caused by shrapnel, were the focus of the investigation.

\section{Image Analysis}

Plain radiographs were carefully reviewed for the existence and localization of shrapnel using a USX-RAY workstation (US-XRAY Röntgen A.Ş, Bolu, Turkey). All CT examinations were completed with a Somatom Emotion Duo CT Scanner (Siemens Healthineers, Siemens Healthcare GmbH, Erlangen, Germany). Windows of soft tissue and bone demonstrated the presence of shrapnel, and multiplanar-reformatted images (MPR) provided a more specific localization of the objects.

\section{Statistical Analysis}

IBM SPSS Statistics for Windows, Version 22.0 (IBM Corp., Armonk, NY, USA) was used to analyze descriptive statistics, as well as the frequency and percentage of discrete variables (injury type, injury location, and injured body region). For continuous variables (i.e., age), mean $\pm S D$ was used. Chi square tests were performed to determine the statistical differences between groups. Statistical significance was established at $p<0.05$.

\section{RESULTS}

The plain radiographs and CT examinations of 90 male cases were analyzed. The mean age of the study group was $30.1 \pm 8$. I years (range: $20-50$ years). Eighty-five cases (94.4\%) had at least I radiographical examination, and 26 cases $(28.9 \%)$ had a CT examination.

For the purposes of the study, 5 body regions were identified: head/neck, thorax/back, abdomen/pelvis/waist, upper extremities, and the lower extremities. The shrapnel distribution according to body region is shown in Table $\mathrm{I}$.

The injuries were divided into 3 groups according to the source of the injury. Long-barreled weapons were responsible for the injury in 47 cases (52.2\%). In 30 of the 90 cases (33.3\%), the injury was caused by an RPG. In the remaining 
Table I. Shrapnel distribution in the body according to weapon type

\begin{tabular}{|c|c|c|c|c|c|c|c|c|c|}
\hline \multirow[t]{3}{*}{ Shrapnel localizations } & \multicolumn{6}{|c|}{ Weapon type } & \multirow{2}{*}{\multicolumn{2}{|c|}{ Total $(n=90)$}} & \multirow[t]{3}{*}{$\mathbf{p}^{*}$} \\
\hline & \multicolumn{2}{|c|}{$\begin{array}{l}\text { Long-barreled } \\
\text { weapon } \\
(n=47)\end{array}$} & \multicolumn{2}{|c|}{$\begin{array}{l}\text { Rocket-propelled } \\
\text { grenade } \\
(n=30)\end{array}$} & \multicolumn{2}{|c|}{$\begin{array}{c}\text { Improvised } \\
\text { explosive device } \\
(n=13)\end{array}$} & & & \\
\hline & $\mathbf{n}$ & $\%$ & $\mathbf{n}$ & $\%$ & $\mathbf{n}$ & $\%$ & $\mathbf{n}$ & $\%$ & \\
\hline Head/neck & 7 & 14.9 & 15 & 50 & 6 & 46.2 & 28 & 31.1 & 0.002 \\
\hline Thorax/back & 8 & 17 & 8 & 26.7 & 5 & 38.5 & 21 & 23.3 & 0.235 \\
\hline Abdomen/pelvis/waist & 7 & 14.9 & 7 & 23.3 & 5 & 38.5 & 19 & 21.1 & 0.171 \\
\hline Upper extremity & 18 & 38.3 & 17 & 56.7 & 5 & 38.5 & 40 & 44.4 & 0.256 \\
\hline Lower extremity & 30 & 63.8 & 13 & 43.3 & 9 & 69.2 & 52 & 57.8 & 0.137 \\
\hline
\end{tabular}

*: Chi square test.

I 3 cases (14.4\%), the injury was caused by an IED. The shrapnel distribution according to weapon type is also shown in Table I. The only statistically significant relationship between weapon type and shrapnel distribution was the large number of head/neck region injuries caused by RPGs and IEDs. The percentage of injuries to the head/neck region was significantly greater than that of other body regions with those 2 weapons $(p=0.002)$.
Shrapnel distribution characteristics according to the type of conflict location were also investigated. The location of the injury was classified as a residential area or a rural area. Shrapnel distribution according to conflict location is shown in Table 2. No statistically significant difference was found between those 2 variables ( $p>0.005)$.

Finally, relationships between weapon type and conflict lo-

Table 2. Shrapnel distribution in the body according to conflict location

\begin{tabular}{|c|c|c|c|c|c|c|c|}
\hline \multirow[t]{3}{*}{ Shrapnel localizations } & \multicolumn{4}{|c|}{ Conflict location } & \multirow{2}{*}{\multicolumn{2}{|c|}{ Total $(n=90)$}} & \multirow[t]{3}{*}{$\mathbf{p}^{*}$} \\
\hline & \multicolumn{2}{|c|}{$\begin{array}{l}\text { Residential area } \\
(n=66)\end{array}$} & \multicolumn{2}{|c|}{$\begin{array}{l}\text { Rural area } \\
(n=24)\end{array}$} & & & \\
\hline & $\mathbf{n}$ & $\%$ & $\mathbf{n}$ & $\%$ & $\mathbf{n}$ & $\%$ & \\
\hline Head/neck & 21 & 31.8 & 7 & 29.2 & 28 & 31.1 & 0.81 \\
\hline Thorax/back & 15 & 22.7 & 6 & 25 & 21 & 23.3 & 0.822 \\
\hline Abdomen/pelvis/waist & 14 & 21.2 & 5 & 20.8 & 19 & 21.1 & 0.969 \\
\hline Upper extremity & 31 & 47 & 9 & 37.5 & 40 & 44.4 & 0.424 \\
\hline Lower extremity & 39 & 59.1 & 13 & 54.2 .3 & 52 & 57.8 & 0.676 \\
\hline
\end{tabular}

Table 3. Relationship between conflict location and weapon type

\begin{tabular}{|c|c|c|c|c|c|}
\hline \multirow[t]{3}{*}{ Weapon type } & \multicolumn{4}{|c|}{ Conflict location } & \multirow[t]{3}{*}{$\mathbf{p}^{*}$} \\
\hline & \multicolumn{2}{|c|}{$\begin{array}{l}\text { Residential area } \\
\quad(n=66)\end{array}$} & \multicolumn{2}{|c|}{$\begin{array}{l}\text { Rural area } \\
(n=24)\end{array}$} & \\
\hline & $\mathbf{n}$ & $\%$ & $\mathbf{n}$ & $\%$ & \\
\hline Long-barreled weapon & 33 & 50 & 14 & 58.3 & \\
\hline Rocket-propelled grenade & 23 & 34.8 & 7 & 28.2 & 0.783 \\
\hline Improvised explosive device & 10 & 15.2 & 3 & 12.5 & \\
\hline
\end{tabular}



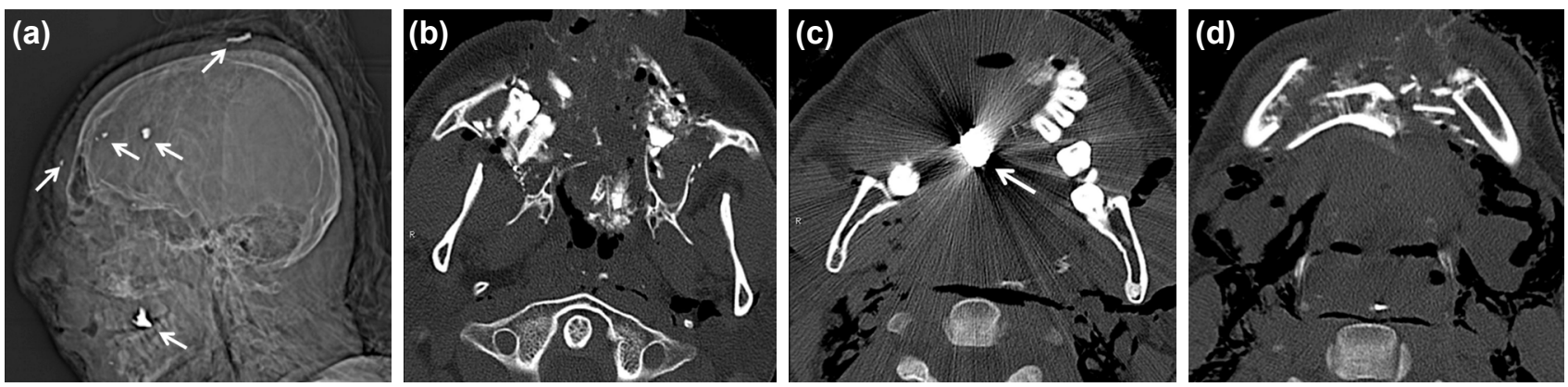

Figure 1. Severe maxillofacial bone fractures and soft tissue damage in a 28-year-old male injured with shrapnel after a rocket-propelled grenade attack. Scanogram (a) shows multiple pieces of shrapnel (white arrows) affecting the maxillofacial and cranial regions. Segmental fractures in the maxillary sinuses, extensive hemorrhage filling the paranasal sinuses, and free air in the soft tissue are readily seen on axial computed tomography images (b and $\mathbf{c}$ ). Also visible is the prominent misalignment of the teeth and dislocation of teeth to the right maxillary sinus and adjacent soft tissue. Segmental fracture of the mandible and extensive free air are seen on (d).

cation were analyzed and the results are presented in Table 3. There were no statistically significant differences between those variables $(p=0.783)$.

In most cases, the shrapnel was located in superficial areas of the body and treated without any intervention other than a simple dressing, removing some fragments in emergency room conditions, and short-term observation. However, II cases had extremity fractures attributable to shrapnel and 5 underwent open surgery. The remaining patients were treated with simple casting. Five cases had vascular damage to the extremities, and surgery using native and prosthetic vascular grafts was performed. Patients who had shrapnel in the head/neck (8 of 28 cases), thorax/ back ( 5 of 2 I cases), and abdomen/pelvis/waist regions (4 of 19 cases), underwent emergency surgery. Those operations were mainly performed to repair maxillofacial bone fractures that caused persistent bleeding and to remove
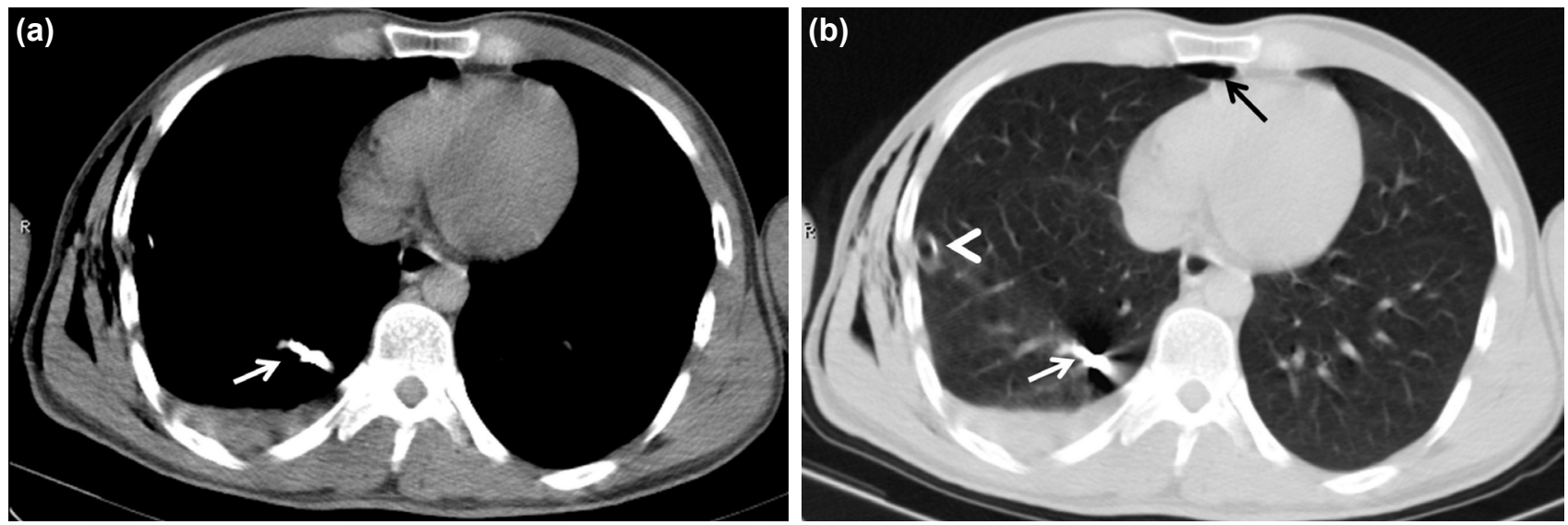

Figure 2. Twenty-five-year-old male injured in a rocket-propelled grenade attack. On axial computed tomography images of the mediastinum and lung window (a and $\mathbf{b}$ ), a piece of shrapnel (white arrow) located in the lower lobe of the right lung causing unilateral mild hemothorax and pneumothorax (black arrow), and subcutaneous emphysema of the lateral side of the right hemithorax is observed. A chest tube (white arrowhead) can also seen in image (b).
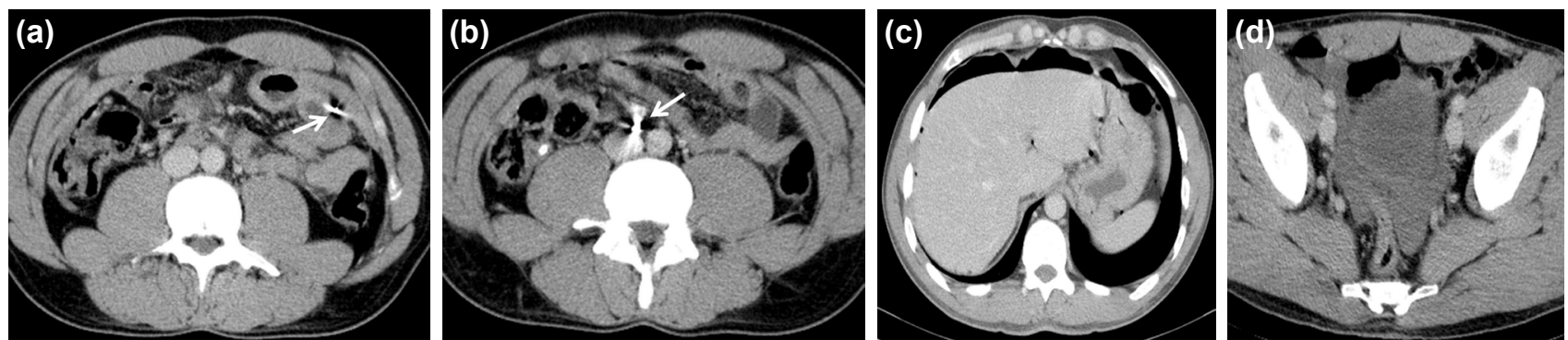

Figure 3. Intra-abdominal shrapnel injury caused by a long-barreled weapon in a 30-year-old male. Axial contrast-enhanced computed tomography images (a and b) reveal 2 small pieces of shrapnel (white arrows) located in the left upper quadrant very close to the inferior vena cava and the abdominal aorta, respectively. In image (c), extensive infradiaphragmatic free air is readily visible. Image (d) shows free fluid in the pelvic region secondary to multilevel small bowel perforation confirmed by laparotomy. 


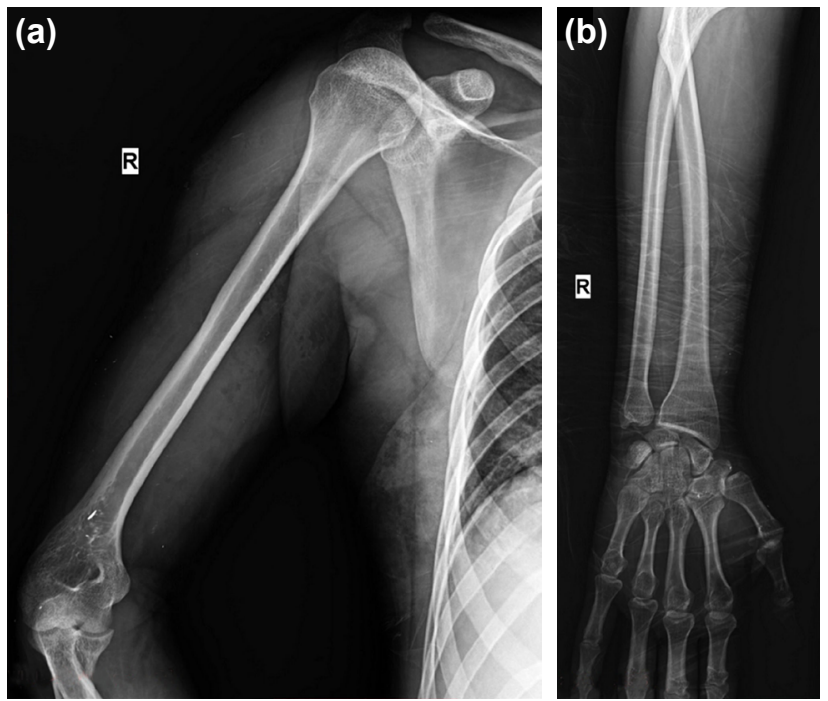

Figure 4. Extensive shrapnel injury affecting the right upper extremity caused by a long-barreled weapon in a 25 -year-old male. Upper extremity X-rays (a and $\mathbf{b})$ demonstrate multiple small pieces of shrapnel affecting the right arm, forearm, and hand regions without causing any fractures.
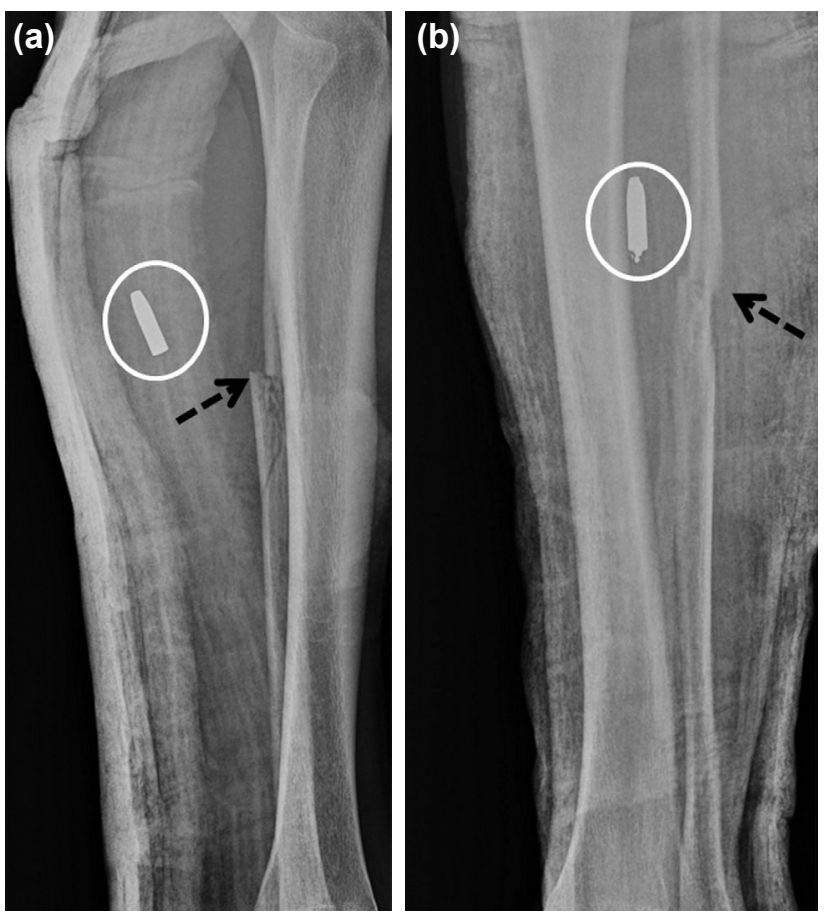

Figure 5. Twenty-five-year-old male injured in a long-barreled weapon attack. Anteroposterior (a) and lateral (b) X-rays reveal a bullet (circle) and multiple pieces of shrapnel in the soft tissue of the leg. A mildly displaced fibular fracture (dashed black arrow) is also visible.

fragments from the lungs and abdomen to establish hemodynamic stability.

\section{DISCUSSION}

In this study, there were significantly more shrapnel injuries affecting the head/neck region as a result of terrorist attacks using RPG and IED weapons, compared with attacks using only long-barreled weapons $(p=0.002)$. However, there was no statistically significant difference found in the shrapnel distribution to other body regions (e.g., thorax/back or extremities). No statistically significant relationship was detected between shrapnel distribution and the type of conflict location (residential or rural). Furthermore, no statistically significant relationship was determined between weapon type (long-barreled weapon, RPG, or IED) and conflict location.

Shrapnel is the term commonly used to describe various types of fragmented material ejected from an explosion. ${ }^{[4]}$ Debris carried by the blast wind causes injury, ${ }^{[7]}$ and the result of the penetration of these fragments is considered a secondary blast injury. ${ }^{[1,2]}$ The distribution of shrapnel in the body is directly affected by tissue resistance; shrapnel will most often travel in a straight line through the body until a bone structure is encountered. ${ }^{[6]}$ However, fragments of certain shapes and dimensions may disperse in various ways and can affect every structure in the body (Figs. 1-5).

A primary part of this study was the analysis of a possible relationship between weapon type and shrapnel distribution. The study hypothesis included the proposition that RPG and IED injuries would be more common in the head/neck and thorax/abdomen regions due to the higher firepower of those weapons compared with long-barreled weapons. During conflicts in which only long-barreled weapons are used, oftentimes the combatants can see one another and may be able to partially protect themselves by sheltering in a covered position. It was hypothesized that this protection would decrease head/neck and thorax/abdomen injuries. On the other hand, due to the unexpected and unpredictable nature of RPG and IED attacks, soldiers often cannot protect themselves, which makes them a more vulnerable target. However, we found a significant difference only in shrapnel injuries to the head/neck region when the injuries resulting from those weapons were compared with longbarreled weapon injuries. The body armor used in all of the study cases likely protected the subjects from thorax/ abdomen shrapnel. Breeze et al. ${ }^{[8]}$ conducted a study characterizing explosive fragments that caused neck injuries in 110 UK service personnel deployed to Afghanistan. They also divided the injuries into groups defined as IED and RPG/ mine injuries and compared fragment shapes in both groups. However, to the best of our knowledge, the medical literature contains no study describing the relationship between shrapnel distribution and weapon type.

At the beginning of this study, it was hypothesized that head/ neck and thorax/abdomen injuries would occur more often in residential area attacks due to the unexpected nature of RPG and IED attacks, and the limited ability of security forces to protect themselves in that environment. In such a location, soldiers may also be distracted by members of 
the community. In rural areas, troops are able to proceed more cautiously and are generally able to be more prepared for extraordinary events. However, we did not detect any relationship between those variables. To the best of our knowledge, there is no other study examining the relationship between shrapnel distribution and conflict location in the medical literature.

Lastly, we investigated a possible relationship between weapon type and conflict location. However, no statistically significant relationship was seen in these variables. Again, we did not find a study of this subject in the medical literature.

Singh et al. ${ }^{[I]}$ reported radiological imaging features of blast injuries seen in 43 patients wounded in the Boston Marathon bombing and mentioned the high percentage of shrapnel injuries. They also indicated that evaluation with radiography and contrast-enhanced CT played an integral part in the diagnostic assessment. Yazgan et al. ${ }^{[9]}$ studied the radiological features of blast-related injuries observed in the 2015 Ankara bombing victims. They also specified that the most common injury pattern was secondary to blast injury, and that the torso was the most commonly injured body part in unarmored civilians. Singh et al. ${ }^{[10]}$ also reported that secondary blast injuries were seen in the patients with abdominal and pelvic injuries who were admitted after the Boston Marathon bombing. In addition, Brook et al. ${ }^{[4]}$ reported their experience using multiplanar CT images to show the trajectory of shrapnel.

This study has some limitations. First, there was no way to know if long-barreled weapons were also used on patients who reported attacks with RPGs or IEDs. This could have affected shrapnel distribution. Second, nonhomogeneous injuries hindered a comprehensive evaluation of injury patterns specific to shrapnel. Third, there were fewer patients exposed to IED shrapnel (I 3 cases) than those injured with long-barreled weapons or RPGs (47 and 30 cases, respectively). Finally, there was a prominent difference between the number of cases where the injury occurred in a residential area and those in rural areas (66 versus 24 cases). These circumstances may have also affected the statistical analysis.
In conclusion, secondary blast injury is caused by high velocity shrapnel and is the most common type of explosion-related injury. These compose the majority of combat-related injuries. Rapid radiological assessment plays an integral role in the evaluation of firearm injuries, and radiologists should be familiar with possible pathologies that can be challenging. In our study, the head/neck region was the location for more shrapnel injuries as a result of RPGs and IEDs compared with other body regions. We believe the main reason for this result is the unexpected nature of these types of attacks; however, more studies are needed to gather further information on the subject.

Conflict of interest: None declared.

\section{REFERENCES}

1. Singh AK, Goralnick E, Velmahos G, Biddinger PD, Gates J, Sodickson A. Radiologic features of injuries from the Boston Marathon bombing at three hospitals. AJR Am J Roentgenol 2014;203:235-9. [CrossRef]

2. Eskridge SL, Macera CA, Galarneau MR, Holbrook TL, Woodruff SI, MacGregor AJ, et al. Injuries from combat explosions in Iraq: injury type, location, and severity. Injury 2012; 43:1678-82. [CrossRef]

3. Champion HR, Holcomb JB, Young LA. Injuries from explosions: physics, biophysics, pathology, and required research focus. J Trauma 2009;66:1468-77. [CrossRef]

4. Brook OR, Eran A, Engel A. CT multiplanar reconstructions (MPR) for shrapnel injury trajectory. Emerg Radiol 2012;19:43-51. [CrossRef]

5. Covey DC. Blast and fragment injuries of the musculoskeletal system. J Bone Joint Surg Am 2002;84:1221-34. [CrossRef]

6. Hollerman JJ, Fackler ML, Coldwell DM, Ben-Menachem Y. Gunshot wounds: 1. Bullets, ballistics, and mechanisms of injury. AJR Am J Roentgenol 1990;155:685-90. [CrossRef]

7. Singh AK, Ditkofsky NG, York JD, Abujudeh HH, Avery LA, Brunner JF, et al. Blast Injuries: From Improvised Explosive Device Blasts to the Boston Marathon Bombing. Radiographics 2016;36:295-307. [CrossRef]

8. Breeze J, Leason J, Gibb I, Allanson-Bailey L, Hunt N, Hepper A, et al. Characterisation of explosive fragments injuring the neck. Br J Oral Maxillofac Surg 2013;51:e263-6. [CrossRef]

9. Yazgan C, Aksu NM. Imaging features of blast injuries: experience from 2015 Ankara bombing in Turkey. Br J Radiol 2016;89:20160063.

10. Singh AK, Sodickson A, Abujudeh H. Imaging of abdominal and pelvic injuries from the Boston Marathon bombing. Emerg Radiol 2016;23:359. [CrossRef] 


\section{ORİIINAL ÇALIŞMA - ÖZET}

\section{Çatışmaya bağlı şarapnellerin dağılım karakteristikleri ile bu dağılımın silah tipi ve çatışma bölgesi ile ilişkisi: Operasyon bölgesi hastanesindeki deneyimler \\ Dr. Sinan Akay, ${ }^{1}$ Dr. Mehmet Burak Aşık, ${ }^{2}$ Dr. Sami Eksert ${ }^{3}$}

${ }^{1}$ Dr. Aşkım Tüfekçi Devlet Hastanesi, Radyoloji Kliniği, Adana

${ }^{2}$ Gülhane Eğitim ve Araştırma Hastanesi, Kulak-Burun-Boğaz Kliniği, Ankara

${ }^{3}$ Gülhane Eğitim ve Araştırma Hastanesi, Anestezi ve Reanimasyon Kliniği, Ankara

AMAÇ: Şarapnele bağlı blastik yaralanmalar çatışmalar sırasında en sık görülen yaralanma şeklidir. Bu çalışmada, şarapnellerin vücuttaki dağıım karakteristiklerini, bu dağıımın silah tipleri ve çatışma bölgeleri ile olası ilişkisini araştırmayı amaçladık.

GEREÇ VE YÖNTEM: Operasyon bölgesinde bulunan hastanemize ateşli silah yaralanması nedeniyle getirilen 246 ardışık hastanın tıbbi kayıtları geriye dönük olarak değerlendirildi. Vücuduna radyolojik olarak kanıtlanmış en az bir şarapnel isabet etmiş olan 90 hasta çalışmaya dahil edildi. Tüm vücut beş bölgeye (baş-boyun, göğüs-sırt, batın-bel, üst ve alt ekstremite) ayrılarak şarapnellerin vücuttaki dağılımı not edildi. Silah tipi (uzun namlulu silah, roket veya el yapımı patlayııı-mayın), çatışma bölgesi (şehir içi ve kırsal alan) ve hastalara ait tüm radyolojik incelemeler (radyografi ve/veya bilgisayarlı tomografi) değerlendirildi. Şarapnel dağılımı ile bu değişkenler arasındaki olası ilişki araştıııldı.

BULGULAR: Roket ve el yapımı patlayıcı-mayın yaralanmaları ile baş-boyun bölgesi yaralanmaları arasında istatistiksel olarak anlamlı ilişkinin dışında $(p=0.002)$ silah tipleri ve şarapnel dağııımı arasında anlamlı fark bulamadık $(p>0.05)$. Şarapnel dağıımı ile çatışma bölgesi arasında ise anlamlı farklıık saptamadik $(p>0.05)$.

TARTIŞMA: Penetran şarapnellere bağlı sekonder blastik yaralanmalar patlayııı ve çatışma ile ilişkili yaralanmaların en sık görülen şeklidir. Bu çalısmada, roket ve el yapımı patlayıcı-mayın ile oluşan yaralanmalarda uzun namlulu silah yaralanmalarına göre baş-boyun bölgesi şarapnel yaralanmalarının belirgin olarak daha yüksek oranda olduğunu bulduk. Bu tip yaralanmaların beklenmedik zamanlarda oluşması ve rutin olarak kullanılmakta olan koruyucu çelik yeleğin torakoabdominal şarapnel yaralanmalarına karşı koruyucu etkisinin bu sonucun ana nedenleri olduğuna inanıyoruz. Anahtar sözcükler: Bilgisayarlı tomografi; blastik yaralanma; çatışmaya bağlı yaralanma; radyografi; şarapnel.

Ulus Travma Acil Cerrahi Derg 2018;24(6):587-593 doi: 10.5505/tjtes.2018.13402 